\title{
Analisis Kejadian Diare di Dusun I Desa Amplas Kecamatan Percut Sei Tuan Kabupaten Deli Serdang
}

\author{
Fitri Dian Nila Sari \\ Universitas Nahdlatul Ulama Sumatera Utara
}

\begin{abstract}
Abstrak
Latar belakang: Diare adalah penyakit yang menyebabkan kematian pertama pada balita. Diperkirakan ratarata 4 miliar diare dan 1,9 juta kematian per tahun. Diare dapat berdampak pada turunnya asupan makanan dan penyerapan nutrisi, gizi buruk, resistens terhadap infeksi, dan gangguan pertumbuhan dan perkembangan kognitif. Tujuan penelitian ini untuk mengetahui determinan yang mempengaruhi kejadian diare di Dusun I Desa Amplas, Percut Sei Tuan.

Metode: Jenis penelitian ini adalah eksplanatori dengan metode cross sectional. Penelitian dilakukan di Desa Amplas Dusun I, Percut Sei Tuan. Pengambilan sampel dengan teknik proportional sampling. Populasi adalah seluruh kepala keluarga di Desa Amplas dusun I, Percut Sei Tuan sebanyak 442 KK. Sedangkan sampel adalah 100 orang ibu-ibu di Desa Amplas Dusun I, Percut Sei Tuan.

Hasil: Berdasarkan hasil uji chi-square memperlihatkan bahwa p-value kualitas fisik air adalah 0,00 atau< nilai sig $\alpha=0,05$. Hal ini membuktikan bahwa kualitas fisik air berhubungan dengan kejadian diare. Hasil uji chi-square memperlihatkan bahwa nilai signifikan probabilitas jarak septic tank adalah 0,00 atau $<$ nilai sig $\alpha$ =0,05. Hal ini membuktikan bahwa jarak septic tank berhubungan dengan kejadian diare.

Kesimpulan: Gambaran keadaan lingkungan persentase terbesar kualitas fisik air bersih dan air minum, jarak septic tank ke sumber air termasuk memenuhi syarat. Ada hubungan antara kualitas fisik air, jarak septic tank ke sumber air dengan kejadian diare.
\end{abstract}

Kata kunci: diare, air, septic tank

\section{Analysis of Diarrhea Case in Dusun I Desa Amplas, Percut Sei Tuan, Deli Serdang}

\begin{abstract}
Background: Diarrhea is the first cause of death in children under five. It is estimated that about 4 billion cases of diarrhea and 1.9 million deaths per year. Diarrhea causes a decrease in food intake and absorption of nutrients, poor nutrition, resistance to infection, and impaired growth and development. The purpose of this study was to determine the factors that influence the incidence of diarrhea in Dusun I Desa Amplas, Percut Sei Tuan

Methods: This type of research is an explanatory study with a cross sectional design with proportional sampling. The research was carried out in Dusun I Desa Amplas, Percut Sei Tuan.. The population in the study were 442 families in Dusun I Desa Amplas. While the sample was 100 women

Result: Based on the results of the chi-square test, it shows that the significant probability value of the physical quality of water is $0.00 \mathrm{or}<$ sig $\alpha=0.05$. It proves that the physical quality of water is related to the incidence of diarrhea. The results of the chi-square test show that the significant value of the probability of the septic tank distance is 0.00 or $<$ sig $\alpha=0.05$. It proves that the distance of the septic tank is related to the incidence of diarrhea.

Conclusion: The largest percentage of the physical quality of water, the distance between the septic tank and the water source is considered eligible. There is a relationship between the physical quality of water, the distance between the septic tank and the water source and the incidence of diarrhea.
\end{abstract}

Key Words: diarrhea, water, septic tank

Korespondensi: Fitri Dian Nila Sari

Email : firawadi16@gmail.com 


\section{PENDAHULUAN}

Terjadi Kejadian Luar Biasa (KLB) diare yang dialami oleh 8 provinsi pada tahun 2018 dan 8 kabupaten/ kota di Indonesia dengan penderita mencapai 756 jiwa dan kematian sebanyak 36 jiwa (CFR 4,76\%). Sedangkan target angka kematian (CFR) saat KLB diare diharapkan $<1 \%{ }^{1}$ Angka ini mengalami penurunan dari sisi jumlah penderita namun peningkatan dari sisi angka kematian, apabila dibandingkan dengan tahun 2017. Pada tahun 2017 terjadi KLB diare, dilaporkan terjadi 21 kali yang terjadi di 12 provinsi dan 17 kabupaten/ kota dengan banyaknya penderita yaitu 1725 jiwa dan yang mengalami kematian sebesar 34 jiwa (CFR $1,97 \%)^{2}$

Angka kesakitan akibat diare mencapai angka 1,7 miliar dan 525.000 penderita mengalami kematian setiap tahunnya berdasarkan WHO tahun 2017. Diare menjadi salah satu penyebab tingginya angka kematian pada anak, hal ini dikarenakan diare berdampak pada tumbuh kembang anak balita yang memicu terjadinya malnutrisi atau kekurangan nutrisi sehingga menyebabkan kematian disetiap tahunnya. ${ }^{3}$ Balita dapat menderita diare sekitar 3,3 kali setiap tahunnya, bahkan sekitar $80 \%$ menimbulkan kematian pada balita usia 0-2 tahun. ${ }^{4}$

Data Riset Kesehatan Dasar (Riskesdas) di tahun 2013, period prevalen diare di Indonesia adalah 4,5\%, dengan insiden diare adalah 3,5\%. Insiden diare pada balita secara nasional tertinggi pada usia $12-23$ bulan sebesar $9,7 \%$ dan terendah pada balita dengan usia 48-59 bulan sebesar 4,2\%. Prevalensi diare berdasarkan tingkat pendidikan terbanyak pada kelompok non pendidikan sebesar $8,0 \%$ dan berdasarkan kelompok umur diare terjadi disemua golongan dengan angka tertinggi terjadi pada balita $(16,7 \%){ }^{5}$

Data Badan Pusat Statistik (BPS) Provinsi Sumatera Utara tahun 2020 menyatakan terdapat 70.243 kasus diare yang tersebar di Provinsi Sumatera Utara dengan Kota Medan sebagai kota terbanyak penderita diare dengan jumlah kasus 8047 orang sedangkan Kabupaten Deli Serdang sebagai kabupaten terparah dengan jumlah kasus 15.185 orang. ${ }^{6}$ Angka ini mengalami penurunan dibandingkan data BPS Provinsi Sumatera Utara pada tahun 2017 jumlah kasus diare yang ditemukan sebanyak 121.262 orang dengan penderita diare di Kota Medan sebanyak 10.225 orang. $^{7}$ Salah satu daerah endemis diare adalah di Kota Medan, berdasarkan laporan dari Dinkes Kota Medan jumlah kasus diare terbanyak terjadi di puskesmas Medan Deli sebanyak 1729 orang. ${ }^{8}$

Diare dapat disebabkan oleh banyak faktor yang memicu diantaranya adalah terbatasnya jamban sehat dengan sistem pembuangan septic tank dan kurangnyua cakupan air bersih yang dapat dikonsumsi oleh masyarakat. Masyarakat di Dusun Deli Serdang masih banyak yang melakukan buang air besar disembarang tempat, hal ini dapat mencemari saran sumber air bersih yang digunakan masyarakat di dusun tersebut. Sumber air bersih utama masyarakat Deli adalah sumur gali dangkal, yang mana sumur gali tersebut mempunyai potensi yang tinggi untuk tercemar oleh mikroorganisme yang berasal dari fases yang dibuang disembarang tempat. Beberapa sebab tersebut menjadi faktor utama yang mempengaruhi terjadinya diare. Sesuai dengan permasalahan yang ada makan, tujuan dari penelitian ini adalah untuk mengetahui faktor resiko yang berhubungan dengan diare di Dusun Deli Serdang.

\section{METODE}

Jenis penelitian ini bersifat deskripsi analitik untuk menggali bagaimana fenomena kesehatan, yang mana dalam hal ini kejadian diare bisa terjadi. Metode yang digunakan adalah cross-sectional dengan melakukan pengukuran dan secara bersamaan antara variabel bebas dan terikat.

Penelitian ini dilaksanakan di Dusun I Desa Amplas Kecamatan Percut Sei, yang menjadi populasi adalah seluruh kepala keluarga sebanyak 442 KK. Sampel penelitian ini yaitu sebahagian dari kepala keluarga sesuai dengan kriteria yang ditentukan, dan responden merupakan para ibu.

Besar sampel dihitung menggunakan rumus Slovin ${ }^{9}$ dengan tingkat kepercayaan $90 \%(\mathrm{~d}=0,1)$ dan jumlah kepala keluarga 442 KK sehingga didapatkan hasil 81,55. Untuk menutupi bias karena menggunakan tingkat kepercayaan $90 \%$, maka hasil yang sudah diperoleh ditambah dengan $10 \%$ × $82=8,2=8$. Sehingga besar sampel yang diperoleh adalah $82+8=90$, peneliti menggenapkannya menjadi 100 orang.

Penelitian ini menggunakan data primer melalui pengisian kuesioner oleh responden 
dan observasi. Analisis data melalui univariat dan bivariat dengan uji statistik chisquare.

\section{HASIL}

\section{Analisis Univariat}

Analisis univariat digunakan untuk melihat karakteristik sampel dalam bentuk tabel dengan variable syarat fisik air dan jarak sumber air dengan septic tank terhadap kejadian diare.

Penyediaan Sarana Air Bersih dan Air Minum

Dari hasil penelitian didapatkan hasil bahwa dari 100 responden, mayoritas responden telah memenuhi syarat fisik air yaitu tidak berasa, berwarna dan berbau yakni 61 responden $(61,0 \%)$. Ada 12 reponden $(22,0 \%)$ yang memiliki sumur berjarak $<10 \mathrm{~m}$ dari septic tank sedangkan 88 responden $(78,0 \%)$ sudah memiliki sumur yang berjarak $\geq 10 \mathrm{~m}$ dari septic tank. Hasi tersebut dapat dilihat pada Tabel 1.

Tabel 1. Distribusi Frekuensi berdasarkan Penyediaan Sarana Air Bersih dan Air Minum di Dusun I Desa Amplas, Percut Sei Tuan

\begin{tabular}{llrr}
\hline No & $\begin{array}{l}\text { Air Bersih dan Air } \\
\text { Minum }\end{array}$ & Jumlah & \% \\
\hline $\mathbf{1}$ & Syarat fisik air & & \\
& Memenuhi syarat & 61 & 61,0 \\
& Tidak memenuhi & 39 & 39,0 \\
& syarat Total & $\mathbf{1 0 0}$ & $\mathbf{1 0 0 , 0}$
\end{tabular}

2 Jarak sumber air dengan jamban

$\begin{array}{crr}<10 \mathrm{~m} & 22 & 22,0 \\ \geq 10 \mathrm{~m} & 78 & 78,0 \\ \text { Total } & \mathbf{1 0 0} & \mathbf{1 0 0 , 0} \\ & \end{array}$

\section{Kejadian Diare}

Dari hasil penelitian didapatkan hasil bahwa dari 100 responden, mayoritas responden tidak diare sebanyak 75 responden $(75,0 \%)$, sedangkan minoritas responden yang menderita diare sebanyak 25 responden $(25,0 \%)$. Hasil tersebut dapat dilihat pada Tabel 2.
Tabel 2. Distribusi Frekuensi berdasarkan Kejadian Diare di Dusun I Desa Amplas, Percut Sei Tuan

\begin{tabular}{clcc}
\hline No & Kejadian Diare & Jumlah & $\mathbf{\%}$ \\
\hline $\mathbf{1}$ & Mengalami & 25 & 25,0 \\
$\mathbf{2}$ & Tidak mengalami & 75 & 75,0 \\
& Total & $\mathbf{1 0 0}$ & $\mathbf{1 0 0 , 0}$ \\
\hline
\end{tabular}

\section{Analisis Bivariat}

Analisis bivariat dipergunakan untuk menganalisis hubungan antara sanitasi dasar dengan diare di Dusun I Desa Amplas, Percut Sei Tuan, Deli Serdang dengan uji chi-square untuk memperlihatkan hubungan antara variabel independen dan variabel dependen.

Berdasarkan tabel tabulasi silang antara sumber air terhadap diare diketahui bahwa pada responden dengan sumber air tidak memenuhi syarat fisik terdapat 39 responden, $19(48,72 \%)$ responden yang mengalami diare, dan $20(51.28 \%)$ yang tidak mengalami diare. Sedangkan pada responden dengan sumber air memenuhi syarat fisik terdapat 61 responden, $6(9,84 \%)$ responden yang mengalami kejadian diare dan $55(90,16 \%)$ responden yang tidak mengalami kejadian diare. Berdasarkan hasil uji chi-square ditemukan bahwa p-value sumber air sebesar 0,00 atau $<$ nilai sig $\alpha=$ 0,05 . Hal ini membuktikan bahwa sumber air mempunyai pengaruh dengan diare.

Berdasarkan tabel 3 diketahui bahwa pada responden yang memiliki jarak sumber air dari septic tank $>10 \mathrm{~m}$ ada 78 responden,7 (8.97\%) responden yang mengalami diare, dan $71(91,03 \%)$ yang tidak mengalami kejadian diare. Sedangkan pada responden yang memiliki sumber air berjarak $<10 \mathrm{~m}$ ada 22 orang $(22 \%), 18$ orang $(81,82 \%)$ responden yang mengalami kejadian diare ada 4 orang $(18.18 \%)$ responden yang tidak mengalami kejadian diare.

Berdasarkan hasil uji chi-square memperlihatkan bahwa nilai signifikan probabilitas jarak septic tank adalah 0,00 atau $<$ nilai sig $\alpha=0,05$. Hal ini membuktikan bahwa jarak septic tank mempunyai pengaruh dengan kejadian diare. 
Tabel 3. Tabulasi Silang antara Syarat Fisik Air dan Jarak Sumber Air ke Septic tank terhadap Kejadian Diare dalam di Dusun I Desa Amplas, Percut Sei Tuan

\begin{tabular}{|c|c|c|c|c|c|c|c|}
\hline \multirow{3}{*}{ Variabel } & \multicolumn{4}{|c|}{ Kejadian Diare } & \multirow{2}{*}{\multicolumn{2}{|c|}{ Total }} & \multirow{3}{*}{ Sig- $\mathbf{p}$} \\
\hline & \multicolumn{2}{|c|}{ Positif } & \multicolumn{2}{|c|}{ Negatif } & & & \\
\hline & $\mathbf{N}$ & $\%$ & $\mathbf{N}$ & $\%$ & $\mathbf{N}$ & $\%$ & \\
\hline \multicolumn{8}{|l|}{ Syarat fisik air } \\
\hline Memenuhi & 6 & 9,84 & 55 & 90,16 & 61 & 100 & 0,00 \\
\hline Tidak memenuhi & 19 & 48,72 & 20 & 51.28 & 39 & 100 & \\
\hline \multicolumn{8}{|c|}{ Jarak sumber air dari jamban } \\
\hline$>10 \mathrm{~m}$ & 7 & 8,97 & 71 & 91,03 & 78 & 100 & 0,00 \\
\hline$<10 \mathrm{~m}$ & 18 & 81,82 & 4 & 18,18 & 22 & 100 & \\
\hline
\end{tabular}

\section{PEMBAHASAN}

\section{Hubungan Kualitas Fisik Air terhadap Kejadian Diare}

Berdasarkan hasil penelitian diketahui pvalue sumber air adalah 0,01 atau $<$ nilai sig $\alpha$ $=0,05$ yang berarti bahwa ada hubungan antara kualitas fisik air dengan diare. Hasil tersebut sesuai dengan penelitian lainnya yang mengemukakan bahwa ada hubungan kualitas fisik air dengan diare. Hal ini bisa terjadi karena kualitas air yang buruk yang ditandai dengan adanya bau, rasa dan berwarna mengindikasikan bahwa air tersebut tercemar oleh mikroorganisme atau bakteri yang dapat menyebabkan diare. Potensi penularan diare dapat berasal dari tercemarnya sumber air bersih yang dimasuki oleh bakteri infeksius. Bakteri tersebut dapat masuk kedalam tubuh melalui wadah tempat makan yang dicuci dengan air yang tercemar, melalui jari-jari tangan dan air minum yang dimasak dengan kurang sempurna. ${ }^{10}$

Diare adalah jenis penyakit waterborne disease yaitu dapat ditularkan melalui perantara air. Faktor yang dominan dalam kasus ini adalah sumber air bersih dan pembuangan fases/tinja. Balita yang menggunakan sumber air bersih yang buruk memiliki risiko 3,28 kali untuk terkena diare. Menurut penulis ada hubungan antara sumber air terhadap kejadian diare karena sumber air minum yang baik akan menjaga seseorang dari serangan berbagai penyakit khususnya penyakit diare. ${ }^{11}$ Tersedianya air bersih dan memenuhi syarat perlu disediakan untuk memenuhi kebutuhan dasar manusia dalam upaya pencegahan dan penyebaran penyakit diare.

\section{Hubungan Jarak Septic Tank terhadap Kejadian Diare}

Berdasarkan hasil penelitian diketahui nilai $p$-value jamban adalah 0,00 atau $<$ nilai $\operatorname{sig} \alpha=0,05$. Hasil ini berarti bahwa jarak septic tank dengan sumber air mempunyai pengaruh terhadap kejadian diare.

Penelitian dilakukan dengan wawancara dan juga observasi sehingga ditemukan bahwa sebagian masyarakat masih menggunakan sumur dan jamban yang tidak memenuhi syarat kesehatan lingkungan, hal ini ditandai dengan letak jamban yang dimiliki oleh masyarakat setempat langsung berdampingan dengan sumur pribadi. Berdasarkan syarat kesehatan, jarak sumur atau sumber air dengan jamban atau sumber pencemar adalah minimal 10 meter untuk menghindari tercemarnya sumber air bersih yang digunakan masyarakat.

Selain sarana sumber air minum, pembuangan tinja yang sembarangan akan memudahkan penyakit diare tersebar dan dapat menular melalui tinja. Jenis tempat pembuangan tinja dan kebiasaan Buang Air Besar (BAB) sembarangan pada keluarga akan meningkatkan kemungkinan terserangnya penyakit diare pada balita bahkan mencapai sebesar 2 kali lipat dibandingkan dengan keluarga yang mempunyai kebiasaan membuang tinja yang memenuhi syarat. ${ }^{12,13}$ Jarak antara sumber pencemar dengan letak sumur gali yang tidak memenuhi ketentuan Permenkes RI Nomor 416 Tahun 1990 yaitu kadar maksimum jumlah total Coliform air perpipaan sebesar $10 / 100 \mathrm{ml}$ dan air non perpipaan sebesar 50/100 $\mathrm{ml}$ (syarat mikrobiologis) juga terbukti memiliki hubungan yang signifikan terhadap kualitas mikrobiologi air (MPN Coliform) sumur gali pada air sumur gali di Desa Pangebatan, Karanglewas, Banyumas. ${ }^{14}$ Dari penelitian lainnya didapati pula bahwa ada hubungan antara jamban, saluran air limbah dan pengelolaan sampah dengan kejadian diare yang dialami oleh balita. ${ }^{15}$ Menurut asumsi penelitian ada hubungan antara jarak septic 
tank terhadap kejadian diare karena sumber air bersih yang memenuhi syarat akan menjaga seseorang dari serangan berbagai penyakit khususnya penyakit diare.

\section{KESIMPULAN}

Berdasarkan hasil penelitian di Dusun I Desa Amplas Kecamatan Percut Sei Tuan, Deli, Serdang didapatkan bahwa 25 orang $(25 \%)$ dari jumlah keseluruhan yang mengalami kejadian diare. Gambaran keadaan lingkungan persentase terbesar kualitas sumber air bersih maupun air minum, jarak septic tank ke sumber air termasuk kategori baik (memenuhi syarat). Ada hubungan signifikan antara sumber air dan diare $(p$-value $<0,05)$. Terdapat hubungan signifikan antara jarak septic tank dan diare $(p$-value $<0,05)$.

\section{DAFTAR PUSTAKA}

1. Kemenkes RI. Profil Kesehatan Indonesia Tahun 2019.; 2019.

2. Untung Suseno Sutarjo MK, Dr. drh. Didik Budijanto MK, drg. Rudy Kurniawan MK, Boga Hardhana, S.Si M, Yudianto, SKM MS. Data dan Informasi - Profil Kesehatan Indonesia (Data and Information - Indonesia Health Profil). Profil Kesehat Indones. 2018.

3. WHO and UNICEF. Progress on Drinking Water, Sanitation and Hygiene: 2017 Update and SDG Baseline. World Heal Organ. 2017.

4. Bin Ahmad Z, Arimbawa IW, Trisna Dew KA. Hubungan Faktor Perilaku dan Faktor Lingkungan terhadap Kejadian Diare pada Balita Di Desa Sukawati, Kabupaten Gianyar Bali Tahun 2014. Intisari Sains Medis. 2016. doi:10.15562/ism.v6il.14

5. Kemenkes R. Riset Kesehatan Dasar Tahun 2013.; 2013.

6. BPS Sumut. Berita Resmi Statistik 2020. Bps.go.id. 2020.

7. Sumut D. Dinas Kesehatan Provinsi
Sumatera Utara. Profil Dinas Kesehat Provinsi Sumatera Utara. 2017.

8. Indriani RA. Analisis Pelaksanaan Program Diare Di Puskesmas Medan Deli Kecamatan Medan Tahun 2014. Jurnal Teknol Kim dan Ind. 2014.

9. Notoatmodjo. Metodologi Penelitian Kesehatan Cetakan Kedua. Rineka Cipta. 2012.

10. Direktorat Kesehatan Keluarga. Laporan Tahunan Direktorat Kesehatan Keluarga. Kementrian Kesehat RI. 2016.

11. Grafika D, Sabilu Y, Munandar S. Faktor Risiko Kurangnya Perilaku Hidup Bersih dan Sehat (PHBS) Tatanan Rumah Tangga Terhadap Kejadian Diare pada Balita di Wilayah Kerja Puskesmas Benu-Benua Kota Kendari tahun 2017. J Ilm Mhs Kesehat Masy. 2017.

12. Wulandari AP. Hubungan Antara Faktor Lingkungan dan Faktor Sosiodemografi Dengan Kejadian Diare Pada Balita di Desa Blimbing Kecamatan Sambirejo Kabupaten Sragen Tahun 2009. Hub Antara Fakt Lingkung dan Fakt Sosiodemografi Dengan Kejadian Diare Pada Balita di Desa Blimbing Kec Sambirejo Kabupaten Sragen Tahun 2009. 2009.

13. Rohmah N, Syahrul F. Hubungan Kebiasaan Cuci Tangan dan Penggunaan Jamban Sehat dengan Kejadian Diare Balita. $J$ Berk Epidemiol. 2017. doi:10.20473/jbe.v5i12017.95-106

14. Lufti F, Risqita I, Anwar MC. Hubungan Jarak Sumber Pencemar dengan Kualitas Mikrobiologis Air Sumur Gali di Desa Pangebatan. $J$ Kesehat Lingkung. 2016.

15. Sudasman FH, Bachtiar A, Laelasari E, Ciptaningtyas R. Factors Associated with The Risk of Diarrhea in Children under Five in Bandung, West Java. In: ; 2019. doi:10.26911/theicph.2019.01.5 